\title{
Kemampuan Berpikir Kritis Siswa Melalui Penerapan Pendekatan Realistic Mathematics Education Berbantuan Media Manipulatif Origami
}

\author{
Nur Fitri Amalia ${ }^{1}$, Subanji ${ }^{2}$, Sri Untari ${ }^{3}$ \\ ${ }^{1}$ Pendidikan Dasar-Universitas Negeri Malang \\ ${ }^{2}$ Pendidikan Matematika-Universitas Negeri Malang \\ ${ }^{3}$ Pendidikan Kewarganegaraan-Universitas Negeri Malang
}

\begin{tabular}{l}
\hline \hline INFO ARTIKEL \\
\hline Riwayat Artikel: \\
Diterima: $30-01-2019$ \\
Disetujui: $20-08-2019$ \\
\hline
\end{tabular}

\section{Kata kunci:}

RME approach; origami manipulative media critical thinking; pendekatan RME; media manipulatif origami; berpikir kritis

\begin{abstract}
ABSTRAK
Abstract: This classroom action research aims to describe the success of the RME approach assisted by origami manipulative media to improve the critical thinking skills of VA class students at SDN 1 Patrang Jember. The study was conducted in two cycles. The research subjects were VA class students. Based on research in the first cycle showed that: (1) learning by teachers reached $89.7 \%$ and by students reached $88.5 \%$ (2) students' critical thinking skills reached $76.8 \%$. The data in the first cycle have not yet reached the criteria for success of the action, so that improvements are made to the second cycle. In the second cycle showed that (1) teacher learning reached $95.9 \%$ and by students reached $93.2 \%$, (2) students' critical thinking skills reached $88.9 \%$. So it can be concluded that the RME approach assisted by origami manipulative media can improve students' critical thinking skills.
\end{abstract}

\begin{abstract}
Abstrak: Penelitian tindakan kelas ini bertujuan untuk mendeskripsikan keberhasilan pendekatan RME berbantuan media manipulatif origami meningkatkan kemampuan berpikir kritis siswa kelas VA SDN 1 Patrang Jember. Penelitian dilaksanakan dua siklus. Subjek penelitian yaitu siswa kelas VA. Berdasarkan penelitian siklus I menunjukkan bahwa (1) pembelajaran oleh guru mencapai $89,7 \%$ dan oleh siswa mencapai $88,5 \%$ (2) kemampuan berpikir kritis siswa mencapai $76,8 \%$. Data siklus I tidak mencapai kriteria tindakan yang berhasil, sehingga dilaksanakan perbaikan dalam siklus II. Data siklus II menunjukkan (1) pembelajaran guru mencapai 95,9\% dan oleh siswa mencapai 93,2\%, (2) kemampuan. berpikir kritis siswa mencapai $88,9 \%$. Dapat disimpulkan bahwa pendekatan RME berbantuan media manipulatif origami mampu meningkatkan kemampuan berpikir kritis siswa.
\end{abstract}

\section{Alamat Korespondensi:}

Nur Fitri Amalia

Pendidikan Dasar

Universitas Negeri Malang

Jalan Semarang 5 Malang

E-mail: nurfitriamalia188@gmail.com

Kebutuhan keterampilan pada abad 21 menjadikan pembelajaran matematika harus membekali siswa agar memiliki keterampilan belajar yang diperlukan untuk bisa sukses dalam bekerja dan berkarir di era masyarakat ekonomi global. Keterampilan belajar tersebut yaitu critical thinking atau berfikir kritis, communication atau komunikasi, collaboration atau kolaborasi dan creative thingking atau berpikir kreatif (Sunardi, Kurniati, Sugiarti, Yudianto, \& Nurmaharani, 2017). Selain itu, tujuan pembelajaran matematika di SD adalah memberikan bekal kemampuan matematisasi sesuai dengan masalah kontekstual, memecahkan masalah, mengomunikasikan gagasan melalui simbol, dan memiliki kemampuan bernalar terhadap masalah (Maulana, 2008; PISA, 2015). Oleh karena itu, pembelajaran dengan mengutamakan proses agar siswa memiliki kemampuan berpikir dan menjadi bermakna sangatlah dibutuhkan.

Kemampuan berpikir kritis dalam pembelajaran matematika sangat penting dimiliki oleh siswa. (Snyder \& Snyder, 2008) mengemukakan bahwa berpikir kritis merupakan hal yang penting, hal ini karena melalui berpikir kritis akan membuat seseorang dengan otomatis dapat menyelesaikan masalah sederhana atupun masalah yang kompleks baik dalam pelajaran maupun di kehidupan Sehari-hari. Pernyataan tersebut diperkuat oleh (Gunn, Grigg, \& Pomahac, 2008) bahwa kemampuan berpikir kritis berimplikasi terhadap mental aktif siswa dalam menyelesaikan permasalahan sehari-hari. Berdasarkan hasil observasi 19 Juli 2018 dapat disimpulkan (1) dari hasil rata-rata pretes kemampuan berpikir kritis siswa kelas VA di SD N 1 Patrang Jember pada kriteria kurang kritis yaitu 63,4\%, (2) peran guru dalam pembelajaran mendominasi, (3) siswa hanya mencontoh hitung cepat dari guru untuk menyelesaikan atau mengerjakan soal pembagian pecahan tanpa memperhatikan keterkaitan masalahan sehari-hari 
dengan materi pembelajaran matematika. Hal ini indikasi bahwa pembelajaran masih berorientasi pada kemampuan kognitif tingkat rendah, (4) aktivitas pembelajaran matematika terbatas kaitannya dengan hitungan tanpa ada keterkaitan dengan kehidupan nyata siswa atau pengalaman siswa (5) siswa masih pasif karena belum dibiasakan menyampaikan atau mengungkapkan ide, gagasan informasi dalam pembelajaran.

Hal yang sama dijelaskan oleh (Laurens, Batlolona, Batlolona, \& Leasa, 2018) yang menemukan bahwa pada umumnya pembelajaran matematika masih berorientasi pada kemampuan kognitif tingkat rendah siswa. Kemampuan kognitif tingkat rendah pada umumnya yaitu siswa diminta untuk menghafal. Permasalahan pembelajaran masih berfokus pada kognitif tingkat rendah biasanya terjadi karena pembelajaran hanya ditujukan untuk mencapai target kurikulum sehingga mengabaikan pemahaman dan penanaman konsep matematika pada siswa (Leasa \& Corebima, 2017). (Jamiah, 2013) menguatkan permasalahan tersebut yaitu peran guru masih mendominasi saat pembelajaran berlangsung, materi ajar yang diberikan guru masih belum disesuaikan dengan karakteristik tingkat perkembangan usia siswa sehingga guru dalam membiasakan dan mengembangkan kemampuan berpikir kritis siswa masih sangat terbatas. Sudah seharusnya tujuan-tujuan pembelajaran matematika tercapai salah satunya mengembangkan kemampuan berpikir siswa, sehingga dibutuhkan rancangan pelaksanaan pembelajaran yang efektif. Salah satu alternatif pelaksanaan pembelajaran matematika agar lebih baik, efektif, dan mampu menyampaikan konsep abstrak matematika dengan menerapkan pendekatan realistic mathematics education.

Pendekatan realistic mathematics education (RME) adalah pendekatan pembelajaran matematika yang memberikan strategi pada siswa untuk membangun konsep matematika dengan penemuan kembali sesuai pengetahuan dan pengalaman siswa dalam kehidupan (Treffers, 1991). Pendekatan RME dalam pembelajaran diawali oleh penyajian masalah nyata yang kontekstual dengan kesesuaian pengalaman, dan pengetahuan informal siswa, penyelesaian masalah dengan media manipulatif origami menjadi penghubung antara pengetahuan informal siswa dengan pengetahuan formal siswa, proses membandingkan siswa melalui diskusi memberi kesempatan pada siswa untuk mengonstruk sendiri pengetahuan baru (Gravemeijer, 1994; Treffers, 1991; Wijaya, 2012). Pendekatan RME dengan langkah-langkah yang terstruktur memfasilitasi siswa untuk menganalisis masalah, membuat rencana untuk memecahkan masalah, mengevaluasi, mengidentifikasi dan menerapkan tindakan yang diperlukan untuk memperbaiki atau kinerja yang benar, dan menilai apakah hasil yang diinginkan tercapai atau tidak, sehingga pendekatan RME dapat meningkatkan kemampuan berpikir kritis siswa (Setianingsih, 2016). Pendekatan RME secara empiris dan spesifik dapat meningkatkan kemampuan berpikir kritis (Asih, Irawan, \& Sa'dijah, 2017; Chasanah, 2010). Hal tersebut diperkuat oleh penelitian RME oleh (Palinussa, 2014) menunjukkan bahwa kemampuan siswa dalam berpikir kritis dengan mengikuti pembelajaran pendekatan RME lebih baik daripada siswa yang mengikuti pembelajaran konvensional. Lebih lanjut adanya kekurangan pendekatan RME yaitu membutuhkan alat peraga yang mendukung, (Hirza, Kusumah, Darhim, \& Zulkardi, 2014) menyarankan penerapan pendekatan RME dalam pembelajaran sebaiknya didukung dengan media manipulatif agar mempermudah siswa untuk menemukan, menyelesaikan masalah, dan membangun atau mengonstruk sendiri konsep matematika dalam pembelajaran. Media manipulatif yang dipilih untuk digunakan adalah media manipulatif origami.

Origami merupakan bahasa jepang yang berarti melipat kertas yang bertujuan untuk menghasilkan berbagai bentuk mainan, alat fungsional, alat untuk peraga serta kreasi-kreasi yang lain. Melalui penerapan pendekatan RME berbantuan media manipulatif origami diharapkan mampu memberikan pembelajaran yang bermakna dan meningkatkan kemampuan berpikir kritis siswa kelas VA SDN 1 Patrang jember. Fenomena pembelajaran yang berlangsung sebelumnya menggunakan metode mekanistik, artinya guru mengajarkan cara cepat dengan rumus diikuti siswa meniru cara guru dan mengerjakan contoh soal yang sama. Sehingga permasalahan pembelajaran yang demikian tidak dapat mengembangkan kemampuan berpikir kritis siswa dengan optimal. Kurang bermaknanya pembelajaran berupa pengetahuan yang berbentuk ingatan semata berdampak pada kemampuan berpikir kritis siswa. Oleh karena itu, pembelajaran matematika di SD sudah semestinya dapat mengembangkan kemampuan berpikir kritis siswa.

Kemampuan siswa berpikir kritis adalah salah satu kemampuan berpikir yang penting dan perlu dimiliki oleh siswa pada pembelajaran matematika abad 21. Kemampuan berpikir kritis atau critical thingking adalah unsur utama dalam konteks mata pelajaran matematika (Vieira \& Vieira, 2005). Kemampuan berpikir. kritis atau critical thinking meliputi kemampuan mengidentifikasi, mengklarifikasi, menganalisis, mengevaluasi dan menyimpulkan (Fisher, 2007). Pentingnya kemampuan berpikir siswa dalam pembelajaran matematika memberikan dampak terhadap pola siswa untuk menyelesaikan masalah dan mengambil keputusan dengan logis (Sa'dijah, 2014). Selain itu, kemampuan siswa berpikir kritis sangat perlu diperhatikan dan dikembangkan untuk bekal kehidupan di masa mendatang. (Windayana, 2007) menjelaskan pendekatan realistic mathematics education adalah pendekatan yang melatih siswa untuk membangun pengetahuannya sendiri dengan berpikir kritis menyelesaikan masalah, pembiasaan siswa menyelesaikan masalah dapat membekali siswa dalam menyelesaikan masalah yang relevan dalam kehidupan. 
Berdasarkan uraian yang dijelaskan di atas, indikator kemampuan siswa berpikir kritis yang diteliti (1) menemukan informasi dalam soal cerita atau mengidentifikasi, (2) menemukan garis besar pertanyaan atau mengklarifikasi, (3) menemukan cara penyelesaian masalah dan menyelesaikan masalah atau menganalisis, (4) memberikan alasan yang logis atau mengevaluasi, serta (5) memberikan kesimpulan dengan mengaitkan konsep. Fokus pada penelitian ini yaitu bagaimanakah penerapan realistic mathematics education berbantuan media manipulatif origami dapat meningkatkan kemampuan berpikir kritis siswa kelas VA SDN 1 Patrang Jember.

\section{METODE}

Metode penelitian yang diterapkan yaitu penelitian tindakan kelas. Model yang digunakan sesuai Kemmis dan Taggart (Arikunto, 2009). Alur penelitian yaitu plan, act and observ, reflect. Pelaksanaan penelitian di SDN 1 Patrang Jember dengan lokasi berada di jalan Bondowoso-Jember, Patrang Kabupaten Jember, Jawa Timur. Subjek adalah siswa kelas VA SDN 1 Patrang Jember semester ganjil 2018/2019 yang berjumlah 22 siswa 12 siswa perempuan dan 10 siswa laki-laki. Penelitian dilaksanakan di SDN 1 Patrang Jember karena peneliti pernah kuliah kerja mengajar terbimbing di kelas VA pada tahun 2017 selama tiga bulan. Oleh karena itu, peneliti mengetahui adanya masalah pembelajaran matematika, khususnya materi pembagian pecahan. Setiap tahun pada materi pembagian pecahan hampir 50\% siswa mendapat nilai dibawah KKM. Guru cenderung mengajar dengan cara cepat hitung. Selain itu, SDN 1 Patrang Jember merupakan salah satu SD favorit dengan rata-rata guru kelas yang masih muda. Keberadaan guru muda memungkinkan untuk melakukan pembelajaran yang kreatif dan inovatif agar siswa mampu memiliki kemampuan berpikir kritis.

Instrumen yang digunakan dalam penelitian ini yaitu lembar observasi kegiatan atau aktivitas guru dan dalam menerapkan pendekatan RME berbantuan media manipulatif origami, lembar observasi berpikir kritis siswa, soal tes cerita soal untuk mengetahui berpikir kritis siswa dan pedoman wawancara. Tes berpikir kritis dilakukan setiap pertemuan. Penelitian dilakukan dua siklus yaitu satu siklus lima pertemuan. Hasil data observasi dianalisis dengan kriteria atau kategori sangat baik, baik, cukup, baik, kurang, sangat kurang. Penerapan pembelajaran realistic mathematics education berbantuan media manipulatif origami ditentukan minimal keberhasilan tindakan yaitu 80\% atau mencapai kriteria baik. Persentase keterlaksanaan keberhasilan kegiatan dihitung dengan menggunakan rumus menurut (Arikunto, 2009). Kriteria keterlaksanaan mengacu pada kriteria menurut (Riduwan, 2012) disajikan pada tabel 1.

$$
\text { Persentase nilai rata-rata }=\frac{\sum \text { Skor Perolehan }}{\sum \text { Skor Maksimum }} \times 100
$$

Tabel 1. Kriteria Keterlaksanan RME berbantuan Media Manipulatif Origami

\begin{tabular}{cl}
\hline Nilai Rata-Rata & \multicolumn{1}{c}{ Kriteria } \\
\hline $81-100$ & Sangat Baik \\
$61-80$ & Baik \\
$41-60$ & Cukup \\
$21-40$ & Kurang \\
$0-20$ & Sangat Kurang \\
\hline
\end{tabular}

Sumber: adaptasi (Riduwan \& Akdon, 2009)

Indikator kemampuan berpikir kritis siwa mengacu indikator oleh (Fisher, 2007). Kemampuan berpikir kritis siswa dianalisis berdasarkan criteria sangat kritis, kritis, kurang kritis dan tidak kritis. Siswa mencapai kriteria berhasil jika kemampuan siswa dalam berpiki kritis mencapai kritis dan minimal 80\% jumlah keseluruhan siswa mendapat skor $\geq 16$. Kriteria kemampuan berpikir kritis siswa diadaptasi dari (Suwito, Yuwono, Parta, \& Irawati, 2017) disajikan dalam tabel 2.

Tabel 2. Kriteria Kemampuan Berpikir Kritis

\begin{tabular}{ll}
\hline \multicolumn{1}{c}{ Kriteria } & \multicolumn{1}{c}{ Rentang Skor } \\
\hline Sangat Kritis & $85 \% \leq \mathrm{K} \leq 100 \%$ \\
Kritis & $70 \% \leq \mathrm{K}<85 \%$ \\
Kurang Kritis & $55 \% \leq \mathrm{K}<70 \%$ \\
Tidak Kritis & $\mathrm{K}<55 \%$ \\
\hline
\end{tabular}

Sumber: adaptasi dari (Parta, 2007) 


\section{HASIL}

Pelaksanaan pembelajaran pendekatan realistic mathematics education berbantuan media manipulatif origami untuk meningkatkan kemampuan berpikir kritis siswa kelas VA SDN 1 Patrang Jember dilakukan selama dua siklus. Satu siklus terdiri atas lima pembelajaran atau pertemuan. Tes kemampuan berpikir kritis dilakukan setiap pertemuan yang berarti 10x tes tulis dalam bentuk soal cerita. Indikator Kemampuan berpikir selain dilakukan tes juga dilakukan observasi selama pembelajaran berlangsung. Pedoman observasi berpikir kritis siswa mencakup kriteria sangat kritis, kritis, kurang kritis, dan tidak kritis. Kemampuan berpikir kritis siswa meliputi mengidentifikasi, mengklarifikasi, menganalisis, mengevaluasi dan menyimpulkan (Fisher, 2007).

Berdasarkan analisis data observasi penerapan pendekatan realistic mathematics education berbantuan media manipulatif origami pada siklus I oleh guru sebesar $89,7 \%$ dengan kriteria "sangat baik", sedangkan skor perolehan siswa yaitu $88,5 \%$ dalam kriteria "sangat baik. Pada pelaksanaan tindakan dua atau siklus II perolehan skor pelaksanaan pembelajaran oleh guru sebesar 95,9\% dan 93,2\% oleh siswa berada dalam kriteria kriteria "sangat baik". Skor perolehan pelaksanaan pembelajaran oleh guru terjadi peningkatan sebesar 6,2\% pada siklus I yaitu 89,7\% meningkat pada siklus II menjadi 95,9\%. Skor perolehan pelaksanaan pembelajaran oleh siswa juga mengalami peningkatan sebesar 4,7\%. Pada siklus I yaitu $88,5 \%$ meningkat pada siklus II menjadi 93,2\%. Hasil observasi siklus I dan II tersebut menunjukkan bahwa pelaksanaan pembelajaran oleh guru dan siswa sudah terjadi peningkatan. Peningkatan pelaksanaan pendekatan RME berbantuan media manipulatif origami oleh guru dan siswa dapat dilihat pada gambar 1 .

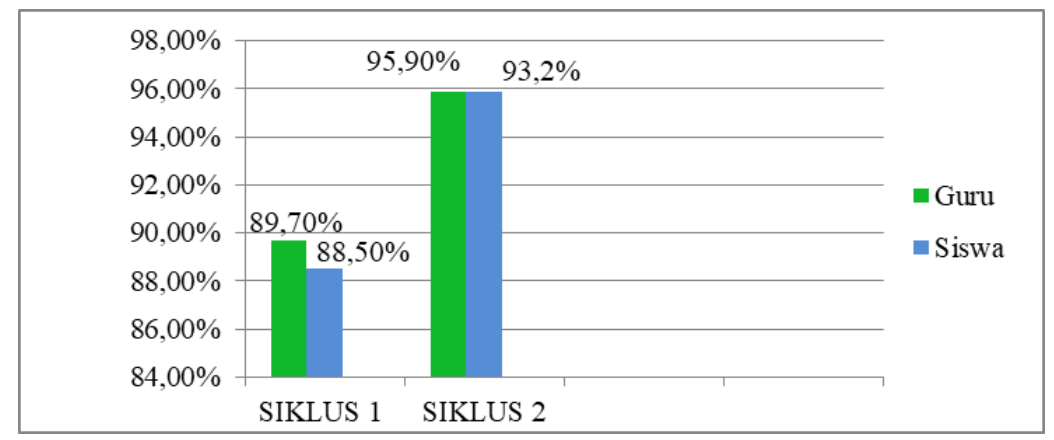

\section{Gambar 1. Diagram Peningkatan Pelaksanaan Pendekatan RME berbantuan Media Manipulatif oleh Guru dan Siswa}

Kemampuan berpikir kritis siswa diukur menggunakan tes dan observasi. Berdasarkan analisis data observasi pada siklus I pertemuan kemampuan berpikir kritis siswa secara klasikal sebesar 69,3\%, pertemuan dua sebesar 76,8\%, pertemuan tiga sebesar 79,5\% dan pertemuan empat sebesar 83,1\%. Secara keseluruhan, kemampuan berpikir kritis siswa berdasarkan observasi pada siklus I sebesar $77,4 \%$ dalam kriteria kritis. Kemampuan berpikir kritis siswa berdasarkan tes pada siklus I pertemuan pertama sebesar 67,7\%, pertemuan kedua sebesar 75,6\%, pertemuan ketiga sebesar 76,8\%, pertemuan keempat yaitu 78,9\% dan pertemuan kelima yaitu $81,8 \%$. berpikir kritis berdasarkan tes kemudian dijumlahkan dengan skor perolehan berpikir kritis berdasarkan observasi yaitu 77,4 +76,2 =76,8 (Kriteria Kritis). Peningkatan kemampuan berpikir kritis siswa pada siklus I dalam setiap pertemuan disajikan pada tabel 3. Tabel peningkatan kemampuan berpikir kritis siswa siklus I dijadikan diagram dapat dilihat pada gambar 2.

Tabel 3. Peningkatan Kemampuan Berpikir Kritis Siswa Siklus I

\begin{tabular}{cccc}
\hline Pertemuan & Skor Perolehan & Nilai Rata-Rata & Kriteria \\
\hline 1 & 67,7 & & \\
2 & 75,6 & & \\
3 & 76,8 & 76,2 & Kritis \\
4 & 78,9 & & \\
5 & 81,8 & & \\
\hline
\end{tabular}




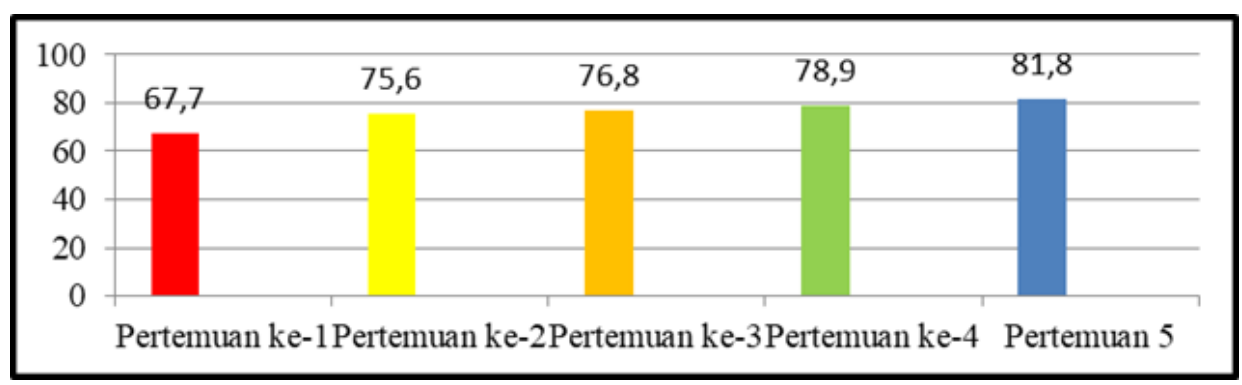

Gambar 2. Diagram Peningkatan Kemampuan Berpikir Kritis Siswa Siklus I

Kemampuan siswa dalam berpikir kritis sudah berada pada kriteria kritis yaitu 76,2\% namun ketercapaian tersebut masih belum sesuai dengan target keberhasilan tindakan sehingga perlu dilakukan perbaikan pada siklus II. Hambatan yang muncul dalam siklus I, yaitu beberapa siswa belum percaya diri dalam menyampaikan ide atau gagasannya hanya sekitar enam siswa yang sangat kritis dalam menjawab, pengelompokkan tidak efektif dengan jumlah anggota 5-6. Beberapa anggota tidak berkontribusi dalam menyelesaikan masalah berpikir kritis, tidak mendapat kesempatan untuk memanipulasi media origami, masih kesulitan dalam memberikan alasan dan menyimpulkan. Kesulitan siswa dalam berpikir kritis mengevaluasi dapat terlihat pada sikus I dapat dilihat pada gambar 3.

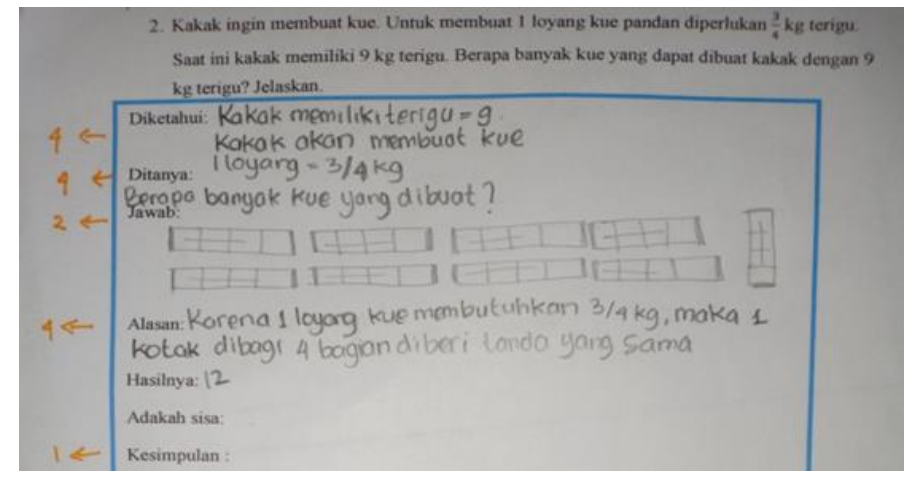

\section{Gambar 3. Diagram Peningkatan Kemampuan Berpikir Kritis Siswa Siklus I}

Siklus II dilaksanakan dengan memperbaiki hal yang kurang dalam1. Pada siklus II setelah dilakukan perbaikan, kemampuan berpikir kritis siswa mengalami peningkatan. Berdasarkan analisis data observasi, kemampuan berpikir kritis siswa siklus II secara klasikal sebesar $88,4 \%$ berada pada kriteria sangat kritis. Secara rinci, kemampuan berpikir kritis siswa pada pertemuan enam sebesar $86,4 \%$, pertemuan kedua sebesar $87,9 \%$, pertemuan ketiga sebesar $89,1 \%$, pertemuan keempat sebesar $90 \%$. Sedangkan kemampuan berpikir kritis siswa berdasarkan tes pada siklus II pertemuan pertama yaitu $84,3 \%$, pertemuan kedua sebesar $86,4 \%$, pertemuan ketiga sebesar 87,3 , pertemuan keempat sebesar $88,6 \%$ dan pertemuan kelima yaitu $89,7 \%$. Skor perolehan tersebut dijumlah dan dipersentase diperoleh data $89,3 \%$ yang berarti kemampuan siswa dalam berpikir kritis siklus II berada pada kriteria sangat kritis. Peningkatan kemampuan berpikir kritis siswa pada siklus II dalam setiap pertemuan disajikan pada tabel 4. Tabel peningkatan kemampuan berpikir kritis siswa siklus II dijadikan diagram disajikan pada gambar 4.

Tabel 4. Peningkatan Kemampuan Berpikir Kritis II

\begin{tabular}{cccc}
\hline Pertemuan & Skor Perolehan & Nilai Rata-Rata & Kriteria \\
\hline 1 & 84,3 & & \\
2 & 86,4 & & \\
3 & 87,3 & 89,3 & Sangat Kritis \\
4 & 88,6 & & \\
5 & 89,7 & & \\
\hline
\end{tabular}




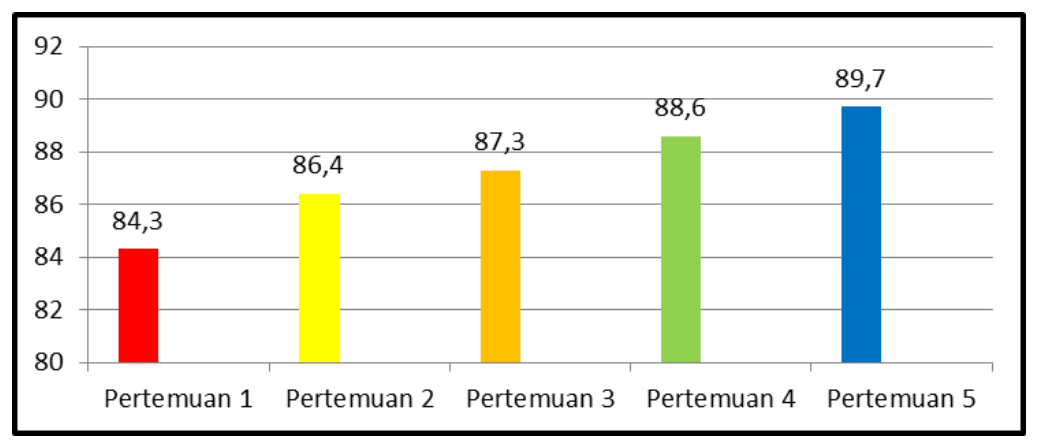

\section{Gambar 4. Diagram Peningkatan Kemampuan Berpikir Kritis Siswa Siklus II}

Peningkatan kemampuan berpikir kritis siswa pada siklus II mencapai kriteria keberhasilan tindakan secara klasikal yang telah ditentukan yaitu $>80 \%$. Peningkatan persentase kemampuan berpikir kritis siswa secara klasikal baik berdasarkan observasi maupun tes pra siklus, siklus I, dan II dapat dilihat pada tabel 5. Berdasarkan tabel 5, dapat dijadikan diagram pada gambar 5 .

Tabel 5. Persentase Peningkatan Kemampuan Berpikir Kritis Siswa secara Klasikal

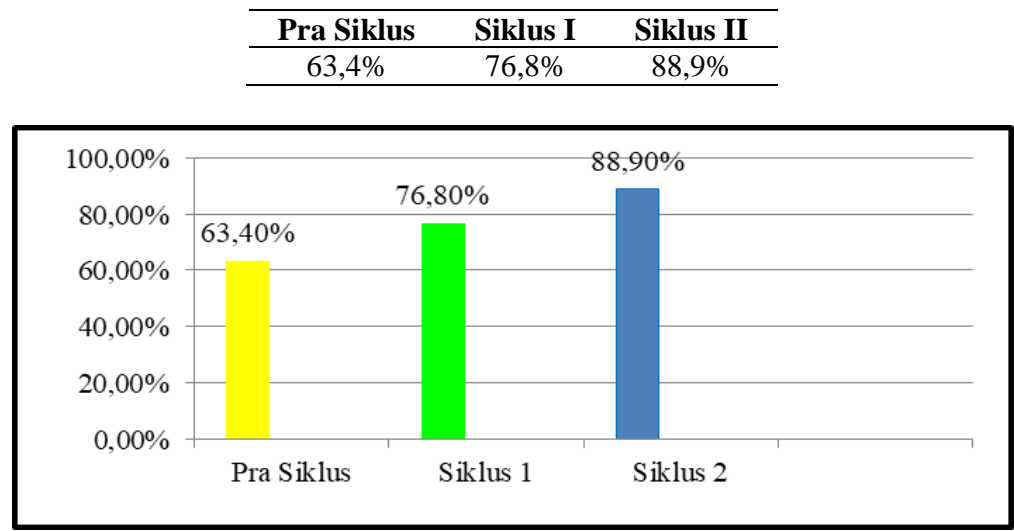

Gambar 5. Diagram Peningkatan Kemampuan Berpikir Kritis

\section{PEMBAHASAN}

Pembelajaran pembagian pecahan matematika melaui penerapan pendekatan RME berbantuan media manipulatif origami dimulai dengan pemberian masalah kontekstual. Melalui pemberian masalah, guru melibatkan siswa untuk dapat berpikir kritis yaitu mengidentifikasi atau menemukan informasi dari masalah kontekstual. Pada langkah pertama ini, siswa sudah mulai melakukan kegiatan mengonstruk pemahamannya melalui penyampaian ide atau gagasan. Penerapan pembelajaran diawali masalah kontekstual sesuai dengan karakteristik RME, yaitu the use of context yang berarti siswa belajar dari masalah yang dekat dan dikenal siswa, sehingga terjadi proses kontruktif, Gravemeijer (Juli, Suwarsono, \& Juniati, 2016). Pembelajaran dengan diawali masalah kontekstual yaitu konteks sesuai pengalaman siswa dapat mengurangi rasa takut siswa dalam pembelajaran matematika. Hal ini didukung oleh pendapat (Jhony, 2012; Keijzer \& Terwel, 2004; Khairunnisak, Amin, Juniati, \& de Haan, 2012) yang menyatakan bahwa pendekatan RME dengan benda nyata dan mengaitkan masalah sehari-hari dapat mengurangi ketakutan dan membuat siswa tertarik mempelajari pecahan matematika. Bimbingan seorang guru dalam memahami masalah yang kontekstual memberikan latihan pada siswa untuk berpikir dalam proses pembelajaran, sehingga pembelajaran menjadi bermakna. Penjelasan tersebut juga didukung oleh penjelasan Crawford (Subanji, 2013) bahwa karakteristik pada pembelajaran kontekstual yaitu relating, experiencing, applying, cooperating dan transferring.

Karakteristik tersebut menjadikan siswa untuk belajar mengaitkan pengetahuan awal yang diketahui dengan pengetahuan formal.

Pada tahap menyelesaikan masalah, guru memfasilitasi siswa untuk menggunakan media origami sebagai alat untuk memecahkan masalah. Melalui media penugasan dalam Lembar Kerja Kelompok, siswa diharapkan dapat berbagi ide dengan temannya untuk menyelesaikan masalah kontesktual dan memberikan alasan dari cara yang telah ditemukan. Siswa dapat melakukan diskusi dalam melakukan pemodelan soal menggunakan media origami. Tahap kedua ini sesuai dengan pernyataan 
(Treffers, 1991) bahwa prinsip pasangan belajar mengajar RME adalah prinsip levels and models. Artinya, siswa dalam pembelajaran terlibat untuk membangun pengetahuan yang dimilikinya melalui pemanfaatan model matematika dalam membentuk konsep formal. Penggunaan media manipulatif kongkret yakni origami yang diotak-atik siswa dalam menyelesaikan masalah dapat menjadikan pembelajaran lebih bermakna dan membantu siswa dalam membangun konsep matematika. Hal tersebut didukung oleh (Burns, 2013) yang menyatakan bahwa media manipulatif dapat membantu siswa untuk memahami ide abstrak menjadi konkret. Dunlap \& Brennan (dalam Lambert, 1996) menyatakan bahwa media manipulatif mempermudah siswa dalam memahami, menemukan dan mengonstruk konsep formal matematika. Oleh karena itu, pendekatan RME dengan bantuan media manipulatif mendukung siswa untuk berpikir kritis mengindentifikasi, mengklarifikasi, menganalisis, mengevaluasi, dan menyimpulkan.

Peran guru dalam memberikan bimbingan pada siswa untuk menemukan cara memecahkan masalah dapat membantu siswa untuk menyelesaikan masalah dalam soal cerita. Kegiatan diskusi atau membandingkan jawaban. Pada tahap ini siswa terlibat aktif berinteraksi (interactivity) bukan hanya dalam satu kelompok namun seluruh kelompok. Setiap kelompok mendapat kesempatan untuk menempelkan hasil diskusinya, membandingkan jawabannya dengan seluruh kelompok. Selanjutnya setiap kelompok mendapat kesempatan yang sama untuk menyampaikan hasil kerja yang sudah dilakukan kemudian kelompok lain memberikan kritik atau melakukan penilaian jika terdapat jawaban yang berbeda. Kegiatan membandingkan dengan memberi kritik atau penilaian dilakukan secara bergantian. Kegiatan ini memberi pengalaman pada siswa untuk berani menyampaikan gagasannya di depan, berani menjawab pertanyaan dari orang lain serta melatih siswa untuk saling memberikan penghargaan. Guru berperan untuk mengorganisasikan jawaban setiap kelompok dan mengarahkan pendapat-pendapat yang diberikan oleh kelompok. Saat pelaksanaan diskusi sedang dilakukan pendidik yaitu guru berperan untuk memediasi siswa memungkinkan pertanyaannya dan menstimulasi siswa agar berpikir kritis. Peran penting guru dalam pembelajaran RME yaitu menjadikan suasana kelas menjadi interaktif yaitu siswa saling memberikan pertanyaan, menjawab, memberikan kritik, menyampaikan ide sehingga guru dapat melihat proses siswa dalam berpikir (Amir, 2016).

Pengelolaan kelas dengan berkelompok juga membantu siswa untuk berlatih berpikir kritis menyimpulkan. Kegiatan menyimpulkan merupakan pengaitan soal cerita dengan konsep matematika yang awalnya verbal diubah menjadi numerik. Kemampuan berpikir kritis menyimpulkan melibatkan kemampuan berpikir kritis mengidentifikasi, mengklarifikasi, menganalisis dan mengevaluasi. Kegiatan ini akan terlaksana dengan baik melalui diskusi dengan kelompok. Melalui diskusi kelompok siswa dapat saling bertukar pemahaman sehingga setiap bisa saling melengkapi. Guru berperan untuk memantau jalannya pemberian kesimpulan, guru harus mampu menampung seluruh jawaban dari kelompok, namun guru tetap memberi penekanan jawaban yang benar agar siswa tidak mendapatkan pemahaman yang salah.

Melalui penerapan RME berbantuan media manipulatif origami, kemampuan siswa dalam mengidentifikasi masalah berada pada kriteria sangat kritis ditunjukkan berdasarkan indikator siswa mampu menyebutkan informasi yang diketahui dengan tepat. Kemampuan siswa dalam mengklasifikasi juga berada pada kriteria sangat kritis ditandai dengan indikator siswa dapat menemukan garis besar inti pertanyaan yang terdapat dalam soal cerita. Kemampuan siswa dalam menganalisis atau mampu menemukan cara penyelesaian masalah berada pada kriteria kurang kritis pada siklus I meningkat menjadi kriteria kritis pada siklus II. Kemampuan siswa dalam mengevaluasi atau kemampuan siswa memberikan alasan juga mengalami kenaikan dari siklus I berada dalam kriteria kurang kritis meningkat menjadi kritis pada siklus II. Selanjutnya, kemampuan berpikir kritis menyimpulkan yang pada awalnya pada siklus I berada dalam kriteria tidak kritis mengalami peningkatan yang cukup pesat pada siklus II berada pada kriteria kritis. Dari penjabaran dalam pembahasan dapat disimpulkan bahwa dalam pembelajaran kemampuan berpikir kritis sangat penting untuk terus dikembangkan dan ditingkatkan agar siswa menemukan dan mengetahui cara terbaik dalam menyelesaikan masalah. Kemampuan siswa mengetahui cara yang terbaik dalam menyelesaikan masalah dapat memberikan bekal dalam menyelesaikan masalah kehidupan nyata.

\section{SIMPULAN}

Dapat disimpulkan bahwa (1) kemampuan berpikir kritis siswa kelas VA SDN 1 Patrang jember meningkat setelah dilakukan penerapan pendekatan realistic mathematics education berbantuan media manipulatif origami. Hal tersebut tampak dari indikator siswa dalam berpikir kritis yaitu mengidentifikasi, mengidentifikasi atau menemukan informasi yang lengkap, mengklarifikasi atau menemukan garis besar pertanyaan, menganalisis atau menemukan cara penyelesaian masalah serta mampu menyelesaikannya, mengevaluasi atau mampu membuat alasan dari jawaban yang diberikan serta menyimpulkan hasil dari soal cerita dengan mengaitkan konsep pembagian pecahan, (2) aktivitas pembelajaran oleh siswa dan guru terlaksana dengan sangat baik melalui pendekatan RME berbantuan media manipulatif origami.

Berdasarkan kesimpulan, saran yang peneliti berikan yaitu (1) dalam menerapkan pendekatan RME berbantuan media manipulatif origami guru perlu menjelaskan langkah-langkah pembelajaran secara terperinci dan jelas hingga siswa dapat menjalankan perannya dalam pembelajaran dengan baik, (2) pembiasaan berpikir kritis perlu dilakukan latihan berulang-ulang dan setiap siswa perlu diperhatikan untuk turut berkontribusi dalam membangun pengetahuan, (3) guru sebaiknya mengelola siswa menjadi kelompok kecil 2-3 anggota dalam satu kelompok agar seluruh anggota mendapat kesempatan memanipulasi 
media, berkontribusi dalam menyelesaikan soal dan mampu menemukan dan membangun pengetahuannya sendiri, (4) pemilihan jenis kertas origami sebaiknya menggunakan jenis HVS karena lebih mudah dilipat, ditandai, dan mudah kering dalam menyerap tinta sehingga siswa lebih cepat dalam mengerjakan dan tidak membuat tangan atau baju siswa kotor.

\section{DAFTAR RUJUKAN}

Amir, M. T. (2016). Inovasi Pendidikan melalui Problem Based Learning. Bandung: Prenada Media.

Arikunto, A. (2009). Metodologi Penelitian. Jakarta: Rajawali Press.

Asih, A. K., Irawan, E. B., \& Sa'dijah, C. (2017). Penerapan Realistic Mathematics Education untuk Meningkatkan Kemampuan Berpikir Kritis Siswa Kelas V. Jurnal Pendidikan: Teori, Penelitian, dan Pengembangan, 2(4), 524-530.

Burns, B. (2013). Improving Student Achievement in Mathematics by Using Manipulatives with Classroom Instruction (11 ${ }^{\text {th }}$ ed.).

Chasanah, F. (2010). Penerapan Pembelajaran PMRI untuk Meningkatkan Kemampuan Berpikir Kritis pada Materi Sistem Persamaan Linier Dua Variabel. UIN Sunan Ampel Surabaya.

Fisher, A. (2007). Critical Thinking: An Introduction (Berpikir Kritis: Sebuah Pengantar). Jakarta: Erlangga.

Gravemeijer, K. P. E. (1994). Developing Realistic Mathematics Education: Utrecht. Center for Science and Mathematics Education, Freudenthal Institute, Utrecht University.

Gunn, T. M., Grigg, L. M., \& Pomahac, G. A. (2008). Critical Thinking in Science Education: Can Bioethical Issues and Questioning Strategies Increase Scientific Understandings. The Journal of Educational Thought, 42(2), 165-183.

Hirza, B., Kusumah, Y. S., Darhim, D., \& Zulkardi, Z. (2014). Improving Intuition Skills with Realistic Mathematics Education. Journal on Mathematics Education, 5(1), 27-34.

Jamiah, Y. (2013). Internalisasi Nilai-Nilai Berpikir Kritis melalui Pengembangan Model Pembelajaran Konsep Matematika Kreatif pada Pendidikan Anak Usia Dini. Jurnal Pendidikan dan Pembelajaran (JPP), 19(2), 229-236.

Jhony, A. (2012). Applying Realistic Mathematics Education in Teaching Geometri in Indonesia. IndoMS-JME, 3(2), 66-75.

Juli, H., Suwarsono, S. T., \& Juniati, D. (2016). The First Cycle of Developing Teaching Materials for Fractions in Grade Five Using Realistic Mathematics Education. IndoMS-JME, 4(2), 172-187.

Keijzer, R., \& Terwel, J. (2004). A Low-Achiever's Learning Process in Mathematics: Shirley's Fraction Learning. Journal of Classroom Interaction, 39(2).

Khairunnisak, C., Amin, S. M., Juniati, D., \& de Haan, D. (2012). Supporting Fifth Graders in Learning Multiplication of Fraction with Whole Number. Journal on Mathematics Education, 3(1), 71-86.

Laurens, T., Batlolona, F. A., Batlolona, J. R., \& Leasa, M. (2018). How does Realistic Mathematics Education (RME) Improve Students' Mathematics Cognitive Achievement. Eurasia Journal of Mathematics, Science and Technology Education, 14(2), 569-578.

Leasa, M., \& Corebima, A. D. (2017). The Effect of Numbered Heads Together (NHT) Cooperative Learning Model on the Cognitive Achievement of Students with Different Academic Ability. Journal of Physics: Conference Series, 795(1), 12071. IOP Publishing.

Palinussa, A. L. (2014). Students' Critical Mathematical Thinking Skills and Character: Experiments for Junior High School Students Through Realistic Mathematics Education Culture-Based. Journal on Mathematics Education, 4(1), 75-94.

Riduwan, A. (2012). Rumus dan Data dalam Aplikasi Statistika. Bandung: Alfabeta.

Sa'dijah, C. (2014). Kepekaan Bilangan Siswa SMP melalui Pembelajaran Matematika Kontekstual yang Mengintegrasikan Keterampilan Berpikir Kreatif. Jurnal Pendidikan dan Pembelajaran (JPP), 20(2), 222-227.

Setianingsih, R. (2016). Implementasi Pendekatan Pembelajaran Matematika Realistik untuk Mengembangkan Keterampilan 4C Siswa Sekolah Dasar. Prosiding Seminar Nasional Matematika, 524-536.

Snyder, L. G., \& Snyder, M. J. (2008). Teaching Critical Thinking and Problem Solving Skills. The Journal of Research in Business Education, 50(2), 90-99.

Subanji, S. (2013). Pembelajaran Matematika Kreatif dan Inovatif. Malang: UM Press.

Sunardi, S., Kurniati, D., Sugiarti, T., Yudianto, E., \& Nurmaharani, R. (2017). Pengembangan Indikator 4c's yang Selaras dengan Kurikulum 2013 pada Mata Pelajaran Matematika SMA/MA Kelas X Semester 1.

Suwito, A., Yuwono, I., Parta, I. N., \& Irawati, S. (2017). Geometry High School Students Thinking Ability Based on Level van Hiele. International Conference on Mathematics: Education, Theory, and Application (ICMETA): Volume 1/2017, June 27th 2017, 200-207.

Wijaya, A. (2012). Pendidikan Matematika Realistik: Suatu Alternatif Pendekatan Pembelajaran Matematika. Yogyakarta: Graha Ilmu.

Windayana, H. (2007). Pembelajaran Matematika Realistik dalam Meningkatkan Kemampuan Berpikir Logis, Kreatif, dan Kritis, serta Komunikasi Matematika Siswa Sekolah Dasar. Jurnal Pendidikan Dasar, 1(8), 1-4. 